\title{
Energy requirement for maintenance and gain for two genotypes of quails housed in different breeding rearing systems ${ }^{1}$
}

\author{
José Jordão Filho ${ }^{2}$, José Humberto Vilar da Silva ${ }^{3}$, Cidinei Trajano Silva ${ }^{4}$, Fernando \\ Guilherme Perazzo Costa $^{5}$, Janaína Maria Batista de Sousa ${ }^{6}$, Patrícia Emília Naves Givisiez ${ }^{7}$ \\ 1 Projeto financiado pelo CNPq. \\ 2 Doutorado Integrado em Zootecnia, CCA/UFPB, Areia - PB; DAP/CCHSA/UFPB, Bananeiras - PB. \\ 3 PDIZ/CCA/UFPB, Areia - PB and PPGTA/CCHSA/UFPB, Bananeiras - PB. Pesquisador do CNPq-1C. \\ ${ }^{4}$ Mestrado em Zootecnia, CCA/UFPB, Areia - PB. \\ 5 PDIZ/CCA/UFPB, Areia - PB. \\ ${ }^{6}$ Mestrado em Tecnologia Agroalimentar, CCHSA/UFPB, Bananeiras - PB. \\ ${ }^{7}$ DZ/CCA/UFPB, Areia - PB.
}

ABSTRACT - This study aimed to estimate the energy requirements for maintenance and gain of Japanese and European quails under growth housed in two rearing systems: floor pens and cages. To determine maintenance requirements, two experiments were conducted with birds housed in cages in environmental chambers (experiment 1) and in floor pens at room temperature conditions (experiment 2). The experimental design was completely randomized with four levels of feed supply (100, 75, 50 and 25\%) and four repetitions. Energy requirements for maintenance were estimated by the comparative slaughter method through a feeding trial. In experiment 1, 64 Japanese and European quails per treatment were housed in cages of climatic chambers at 18,24 , and $28{ }^{\circ} \mathrm{C}$, while in experiment 2, 352 quails per treatment were housed in floor pens at room temperature $\left(26^{\circ} \mathrm{C}\right)$. To estimate gain requirements, five slaughters were performed with quails receiving feed ad libitum and housed under controlled temperature of $18{ }^{\circ} \mathrm{C}$ (experiment 3). Prediction equations were obtained to estimate requirements for maintenance and gain of energy for the two genotypes of quails. The room temperature and breeding system affected the estimates of energy requirements for maintenance. The genotypes presented different estimates for maintenance and gain. Prediction models should be developed considering the room temperature and quails' genotypes.

Key Words: breeding system, energy, modeling, temperature

\section{Introduction}

Globally, quail production stands out for its advantages over other bird species, such as less need for breeding space, sexual precocity, longevity, quick working capital, heat tolerance and resistance to diseases that normally attack other birds. Quails produce nutritious meat and eggs for human consumption and produce at least five generations per year (Silva et al., 2007).

Geographically, quails’ production is divided into two groups: one Asian group, represented by the Japanese quails, small poultry and high egg production and a group of European quails, consisting of improved poultry for meat production which produce eggs larger than those from Japanese quails, but to a lesser extent (Silva \& Costa, 2009). Energy is the main component in feed formulation for all animal species since it regulates food intake. As quails have higher feed intake than hens in the live weight proportion (Silva et al., 2007), consumption of diets with inadequate energy levels can alter consumption and reduce performance.
Studies on poultry requirements by factorial methods involve physiological processes of maintenance and gain. The maintenance energy includes the sum of spending with the basal metabolism with heat production and with normal activities (Emmans, 1994), such as walking on the facilities. On the other hand, the energy gain depends mainly on the efficiency of energy use for deposition of body tissue.

Among the changes required by the European Union to comply with the legislation of animal welfare is the change of the breeding system in cages to floor, allowing poultry to have its natural behavior and habits, which reduces stress (Silva et al., 2006) and demands management changes affecting energy nutritional specifications. Rabello et al. (2004) determined 20\% increase in energy requirement for maintenance in broiler breeders housed on the floor compared with broiler breeders in cages, as the largest floor space caused increased locomotor activity.

Knowledge of nutritional requirements of quails at different thermal conditions allows the development of feeding plans aiming at the thermal comfort of quails, since 
hosting temperature is one of the main stressors. Animals under stress have metabolic changes, expressed by biochemical and behavioral changes that need further investigation.

The purpose of this study was to estimate the energy requirements for maintenance and gain of European and Japanese quails housed at different temperatures and two breeding systems from 16 to 36 days old.

\section{Material and Methods}

The experiment was conducted at the Laboratório de Pesquisa em Nutrição de Aves (LPNA), in Centro de Ciências Humanas, Sociais e Agrárias of UFPB, located in the municipality of Bananeiras, Paraíba, Brazil.

Estimates of maintenance requirements and weight gain in energy were determined in two commercial genotypes of quails (Japanese and European) in the period from 16 to 36 days of age, housed in two production systems: cages (with air-conditioning) and floor pens at room temperature with the purpose of observing genotypes and temperature on the estimates.
A completely randomized design with four treatments and four replications was used. Treatments consisted of feed supply levels of 100, 75, 50 and 25\% ad libitum feeding, whereas $25 \%$ consumption level was determined by the prediction model proposed by Silva et al. (2004ab) in order for quails to consume nutrients below the maintenance.

Diet was formulated based on corn and soybean meal (Table 1), following the suggestions of the Table for quails' nutrient requirements (Silva \& Costa, 2009). In experiment 1 the metabolizable energy requirements for maintenance of Japanese (C. coturnix japonica) and European (C. coturnix coturnix) quails in cages were determined. Sixty-four quails from each genotype, equally produced in climate chambers at 18,24 and $28^{\circ} \mathrm{C}$ were used to estimate the temperature effect on the maintenance requirements and propose prediction equations corrected by the temperature effect. The galvanized wire cages measuring $33 \times 33 \times 16 \mathrm{~cm}$ were kept with four poultry each to provide housing density close to those on the floor pen.

In experiment 2 the energy requirements for maintenance of poultry housed in floor pens were estimated. Three hundred and fifty-two poultry of each genotype were

Table 1 - Food and nutritional composition of experimental diets ${ }^{1}$

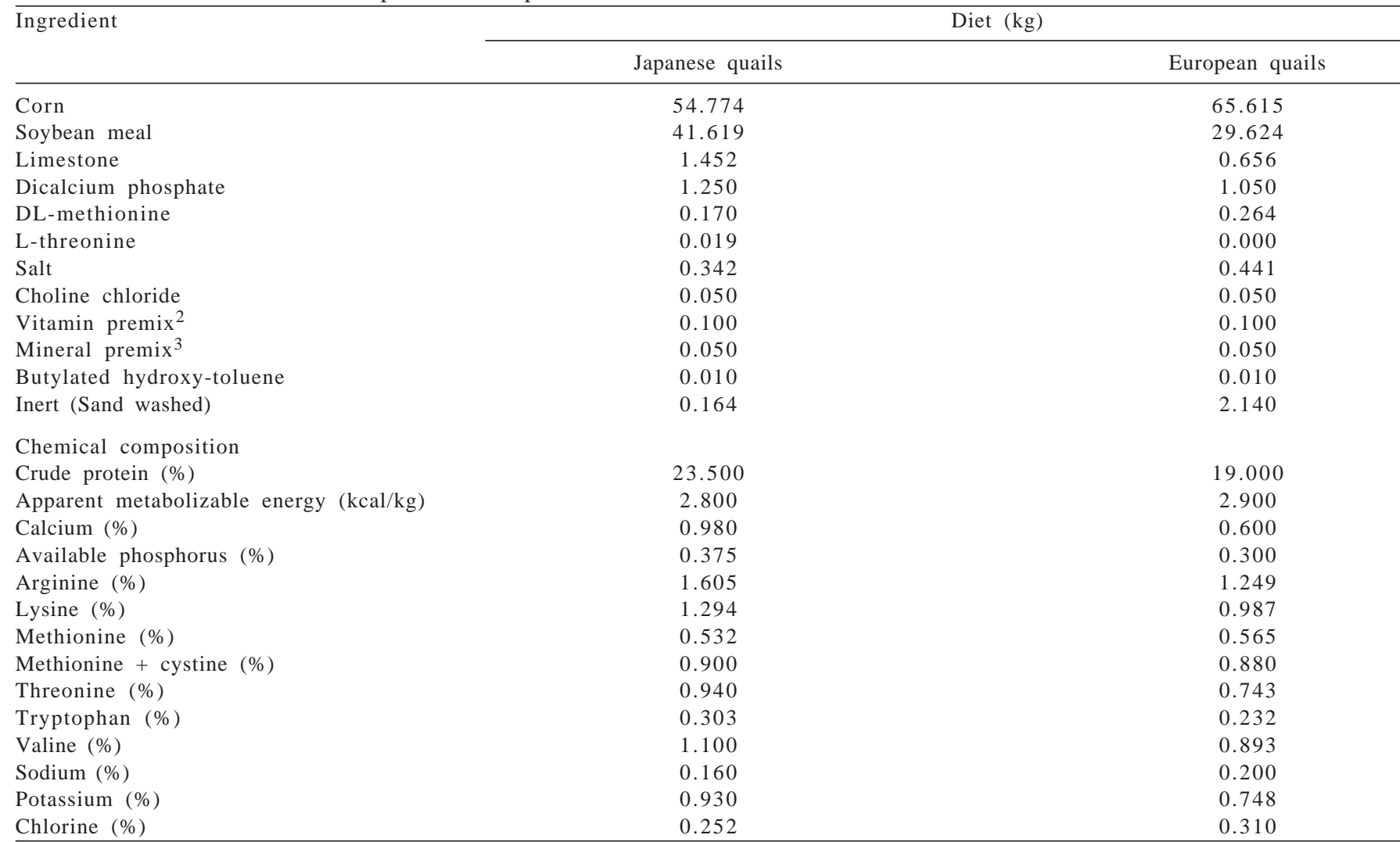

${ }^{1}$ Recommendations of Silva \& Costa (2009).

2 Product composition/kg: vit. A - 10,000,000 IU, vit D3 - 2,500,0000 IU, vit. E - 15,000 mg, vit. K - 2,000 mg, vit. B $-2,000$ mg, vit. B $-4,000$ mg, vit. B ${ }_{6}-4.000$ mg, vit. $B_{12}-15,000 \mathrm{mg}$, vit. C - 50,000 mg, Niacin - 30,000 mg, Biotin - $60 \mathrm{mg}$, folic acid - $500 \mathrm{mg}$, Pantothenic acid - $16,000 \mathrm{mg}$; BHT - $125 \mathrm{mg}$.

${ }^{3}$ Product composition/kg: Zn - 110,000 mg, Se - 360 mg; I - 1,400 mg, Cu - 20,000 mg; Mn - 156,000 mg; Fe - 96,000 mg. 
weighed at 16 days and distributed by weight range infloor pens, measuring $1.0 \times 1.5 \mathrm{~m}$, totaling 22 poultry per plot. Meshed floor pens were equipped with pendulous drinker, a child-tube feeder and 60-watt incandescent bulbs, and the floor was covered with litter of wood shavings. Poultry received natural and artificial light for 24 hours, and the average temperature recorded in the shed was $26 \pm 0.5^{\circ} \mathrm{C}$.

Energy requirements for maintenance of quails were estimated by the comparative slaughter method. For this, a group of 50 quails of each genotype were slaughtered at 16 days of age (slaughter reference) and all poultry of plots were slaughtered at the end of the experiment, when the quails were 36 days old, assuming that body composition of initial poultry slaughter group represents the body composition of the entire population (Wolynetz \& Sibbald, 1987). The reference group of 50 poultry was chosen based on $\pm 5 \%$ the standard deviation of mean live weight of quails at 16 days old.

Prior to slaughter, poultry were solid-fasted for 24 hours. Afterwards, they were weighed to determine the empty body weight and finally killed by cervical dislocation, avoiding the loss of blood and feathers to allow the evaluation of nutrients and energy deposition in the body.

Quail's empty body was identified and stored in a freezer. It was then ground into cutter-type meat grinder three consecutive times to allow the withdrawal of representative samples for analysis. Samples were weighed and placed in oven with forced ventilation at $55^{\circ} \mathrm{C}$ for 72 hours for pre-drying. Later, they were again ground using the cutter for two consecutive times and once in a Willey mill and taken to the laboratory for analytical determinations as recommended by Silva \& Queiroz (2002).

To determine the dry matter content greenhouse ventilation and forced air circulation at $105^{\circ} \mathrm{C}$ were performed for 4 hours. Crude protein values were obtained by the Kjeldahl method and ether extract values determined by fat extraction with hexane in Soxhlet apparatus. Mineral matter was determined after burning in an oven at $600{ }^{\circ} \mathrm{C}$ for four hours (AOAC, 1990) and gross energy was determined by Parr-type adiabatic calorimeter bomb.

The energy retained in poultry body of each plot was calculated as the difference between the amount of energy in the empty body of poultry slaughtered at the end of the experiment and the amount present in the body of poultry slaughtered at the beginning of the experiment. Maintenance requirements were determined by linear regression of retained energy in the empty body in terms of energy consumption. The line intercept with the $\mathrm{X}$ axis was interpreted as the maintenance requirement of dietary energy, while the regression coefficient (parameter "b") indicated the efficiency of energy utilization for weight gain. According to Farrell (1974), the net energy for maintenance was estimated by the exponential regression of heat production as function of metabolizable energy ingested when extrapolated to zero power consumption, according to methodology presented by Lofgreen \& Garrett (1968). Heat production was estimated by the difference between metabolizable energy intake and energy retention.

The energy requirement for maintenance as function of climate chambers' temperature allowed isolating the temperature effect on the estimates in the prediction model.

In experiment 3 the energy requirement for weight gain of Japanese and European quails was determined by using poultry from initial and final slaughters and a flock of 90 poultry, which was slaughtered in three intermediate stages. These groups of poultry were reared and full fed on experimental diet according to methodology described by Albino et al. (1994) and Silva et al. (2004ab). Each intermediate group consisted of three repetitions of ten quails and slaughtered at 21, 26 and 31 days of age. Quails were housed in a climatic chamber at $18.6 \pm 0.6{ }^{\circ} \mathrm{C}$. Feed intake, poultry weight, weight gain and subsequently, the energy retention in empty body in addition to the proximal composition were determined similarly to the analytical and bromatological procedures conducted on samples from the maintenance group.

The net energy requirement for body gain was estimated by the regression of retained energy as function of the empty body weight of quails in the five slaughter periods (16, 21, 26, 31 and 36 days) with parameter "b" as the requirement in $\mathrm{kcal} / \mathrm{g}$ of metabolizable energy for weight gain. Meanwhile, gain requirement was calculated by the ratio of net energy requirement value with use efficiency determined in tests for maintenance.

\section{Results and Discussion}

The metabolizable energy intake decreased as dietary restriction became more severe, with effects on the results of retained energy and production of body heat of Japanese and European quails (Table 2).

The increase in temperature reduced the energy consumption of poultry, so that the lowest energy consumption was observed for the quails kept in the environment of higher temperature, coinciding with their increased body heat production, possibly in an attempt to reduce the production of metabolic heat and thus keep the body's homeothermy. This result has been observed in chickens (Longo et al., 2006), layers (Sakomura et al., 2005) 
Table 2 - Consumption of metabolizable energy, retained energy in the empty body and heat production of quails in cages and floor pens with four feed levels

\begin{tabular}{|c|c|c|c|c|c|c|}
\hline \multirow{2}{*}{$\begin{array}{l}\text { Feed } \\
\text { supply } \\
(\%)\end{array}$} & \multicolumn{3}{|c|}{ Japanese quails } & \multicolumn{3}{|c|}{ European quails } \\
\hline & $\begin{array}{l}\text { Energy consumption } \\
\text { (kcal/day) }\end{array}$ & $\begin{array}{c}\text { Retained energy } \\
\text { (kcal/day) }\end{array}$ & $\begin{array}{l}\text { Heat production } \\
\text { (kcal/day) }\end{array}$ & $\begin{array}{l}\text { Energy consumption } \\
\text { (kcal/day) }\end{array}$ & $\begin{array}{l}\text { Retained energy } \\
\text { (kcal/day) }\end{array}$ & $\begin{array}{c}\text { Heat production } \\
\text { (kcal/day) }\end{array}$ \\
\hline & \multicolumn{6}{|c|}{ Cage at $18{ }^{\circ} \mathrm{C}$} \\
\hline 100 & $63.33 \pm 0.96$ & $8.18 \pm 1.03$ & $55.15 \pm 0.70$ & $75.23 \pm 2.24$ & $14.36 \pm 0.29$ & $60.87 \pm 2.05$ \\
\hline 75 & $42.09 \pm 1.02$ & $3.42 \pm 0.12$ & $38.67 \pm 1.01$ & $56.81 \pm 1.05$ & $5.35 \pm 0.15$ & $51.45 \pm 1.04$ \\
\hline 50 & $27.72 \pm 0.27$ & $0.70 \pm 0.08$ & $27.02 \pm 0.31$ & $35.22 \pm 1.32$ & $0.33 \pm 0.11$ & $34.82 \pm 1.23$ \\
\hline \multirow[t]{2}{*}{25} & $12.89 \pm 0.23$ & $-0.21 \pm 0.06$ & $12.68 \pm 0.20$ & $18.58 \pm 0.32$ & $-1.21 \pm 0.13$ & $19.79 \pm 0.29$ \\
\hline & \multicolumn{6}{|c|}{ Cage at $24{ }^{\circ} \mathrm{C}$} \\
\hline 100 & $52.60 \pm 2.20$ & $8.32 \pm 0.82$ & $44.28 \pm 1.70$ & $74.01 \pm 1.63$ & $13.42 \pm 0.56$ & $60.59 \pm 1.95$ \\
\hline 75 & $35.95 \pm 1.13$ & $3.05 \pm 0.32$ & $32.90 \pm 0.97$ & $55.16 \pm 1.19$ & $5.28 \pm 0.26$ & $49.88 \pm 1.25$ \\
\hline 50 & $24.05 \pm 0.79$ & $0.52 \pm 0.08$ & $23.53 \pm 0.80$ & $37.34 \pm 1.09$ & $1.20 \pm 0.20$ & $36.14 \pm 1.20$ \\
\hline \multirow[t]{2}{*}{25} & $11.21 \pm 0.95$ & $-1.07 \pm 0.12$ & $12.28 \pm 0.79$ & $18.81 \pm 0.44$ & $-0.99 \pm 0.08$ & $19.81 \pm 0.48$ \\
\hline & \multicolumn{6}{|c|}{ Cage at $28{ }^{\circ} \mathrm{C}$} \\
\hline 100 & $52.23 \pm 1.64$ & $8.86 \pm 0.32$ & $43.37 \pm 1.73$ & $73.05 \pm 0.77$ & $14.27 \pm 0.55$ & $58.78 \pm 0.67$ \\
\hline 75 & $37.56 \pm 1.53$ & $3.22 \pm 0.12$ & $34.34 \pm 1.56$ & $55.01 \pm 0.94$ & $5.45 \pm 0.39$ & $49.56 \pm 0.92$ \\
\hline 50 & $25.15 \pm 1.62$ & $1.13 \pm 0.07$ & $24.02 \pm 1.61$ & $36.71 \pm 0.37$ & $0.43 \pm 0.16$ & $36.28 \pm 0.45$ \\
\hline \multirow[t]{2}{*}{25} & $11.72 \pm 0.56$ & $-1.45 \pm 0.06$ & $13.17 \pm 0.58$ & $18.27 \pm 0.32$ & $-1.05 \pm 0.12$ & $19.32 \pm 0.27$ \\
\hline & \multicolumn{6}{|c|}{ Floor pen at $26{ }^{\circ} \mathrm{C}$} \\
\hline 100 & $71.65 \pm 0.39$ & $12.04 \pm 0.61$ & $59.60 \pm 0.98$ & $91.93 \pm 0.34$ & $14.51 \pm 0.18$ & $77.42 \pm 0.39$ \\
\hline 75 & $54.26 \pm 0.51$ & $8.14 \pm 0.53$ & $46.12 \pm 0.38$ & $65.11 \pm 0.46$ & $8.11 \pm 0.19$ & $57.00 \pm 0.51$ \\
\hline 50 & $40.83 \pm 0.15$ & $2.30 \pm 0.15$ & $38.53 \pm 0.29$ & $44.31 \pm 0.65$ & $2.53 \pm 0.25$ & $41.78 \pm 0.83$ \\
\hline 25 & $17.17 \pm 0.11$ & $-0.15 \pm 0.04$ & $17.31 \pm 0.19$ & $21.59 \pm 0.45$ & $-0.95 \pm 0.10$ & $22.54 \pm 0.54$ \\
\hline
\end{tabular}

and breeders (Rabello et al., 2004). Normally, in order to prevent excessive rise in body temperature, poultry reduce endogenous heat production through physical, behavioral and endocrine mechanisms.

Poultry housed in the floor pens had higher power consumption compared with those housed in cages due to the higher energy expenditure through locomotion.

Quails subjected to severe feeding control (25\% ad libitum) had negative energy retention, probably by energy consumption below the maintenance, which increased body reserves' mobilization. Highest energy consumption of European quails caused greater energy retention compared with Japanese quails. The difference between heat production of European and Japanese quails housed in floor pens fed ad libitum was $17.82 \mathrm{kcal} /$ day, which when converted by metabolic weight resulted in $27.8 \mathrm{kcal} / \mathrm{kg}^{0.75} /$ day (282.5 versus $254.7 \mathrm{kcal} / \mathrm{kg}^{0.75} /$ day), suggesting higher metabolic rates for European quails. This result confirms reports of Lopez \& Leeson (2005), who found differences of $20 \mathrm{kcal} / \mathrm{kg}^{0.75} /$ day between commercial broilers and Leghorn roosters with age between 10 and 42 days. Marsden and Morris (1987) observed in Leghorn pullets increased heat production, $16.1 \mathrm{kcal} / \mathrm{kg}^{0.75} /$ day, compared with red pullets. These preliminary observations suggest that different genotypes of quails have distinct characteristics such as different feed conversion and that the European quail is probably more efficient than the Japanese one.
The increased heat production of European quails in relation to the Japanese can be attributed to the higher rate of body growth, represented by the major protein and lipid deposition, although locomotor activity of Japanese quails is responsible for a considerable part of the heat production of this species. Similar results have been observed in broilers with higher heat production (Sakomura et al., 2003) compared with pullets (Neme et al., 2005).

From values of retained energy as function of energy consumption (Table 2) the regression equations for maintenance energy requirements of quails housed in climatic chambers at 18,24 and $28^{\circ} \mathrm{C}$ were obtained, estimated respectively at $94.82,93.10$ and $92.84 \mathrm{kcal} / \mathrm{kg}^{0.75} /$ day for Japanese quails and $107.85,105.98$ and $103.84 \mathrm{kcal} / \mathrm{kg}^{0.75} /$ day for European quails (Table 3).

The metabolizable energy requirement for maintenance decreased with increasing temperature of climate chambers for quails of both genotypes (Figure 1).

Reduction in the energy requirement for maintenance with increasing temperature can be justified by the lower need for metabolic deviation of energy to heat production when temperature favors body thermal homeostasis. The heat generated by metabolic processes and the heat received from the environment was controlled avoiding dissipation of metabolic heat from quails body to the environment. The reduced need to dissipate body heat reflected in increased efficiency of energy utilization for 
Table 3 - Regression equations of energy retained and/or heat production as function of metabolizable energy intake, maintenance requirements and efficiencies of energy use in European and Japanese quails housed in two breeding systems

\begin{tabular}{|c|c|c|c|c|c|}
\hline \multirow[t]{2}{*}{ Equation } & \multirow[t]{2}{*}{$\mathrm{r}^{2}$} & \multirow{2}{*}{$\begin{array}{c}\text { Metabolic } \\
\text { weight }\left(\mathrm{kg}^{0.75}\right)\end{array}$} & \multicolumn{2}{|c|}{ Energy requirement (kcal/kg0.75/day) } & \multirow{2}{*}{$\begin{array}{c}\text { Efficiency of } \\
\text { maintenance } \\
\text { energy }(\%)\end{array}$} \\
\hline & & & Maintenance & Net of maintenance & \\
\hline & \multicolumn{5}{|c|}{ Japanese quails in cages } \\
\hline Cage at $18{ }^{\circ} \mathrm{C}$ & & & & & \\
\hline $\begin{array}{l}\text { Retained energy }=-3.2882+0.1724 \\
\text { *Energy consumption }\end{array}$ & 0.93 & 0.204 & 94.82 & - & 0.17 \\
\hline $\begin{array}{l}\text { Heat production }=10.794 * \mathrm{e} \\
0.0275^{*} \text { Energy consumption }\end{array}$ & 0.93 & 0.204 & - & 52.19 & - \\
\hline $\begin{array}{l}\text { Retained energy }=-4.3039+0.2274 \\
\text { *Energy consumption }\end{array}$ & 0.94 & 0.201 & 93.10 & - & 0.23 \\
\hline $\begin{array}{l}\text { Heat production }=9.9474 * \mathrm{e} \\
0.0303 * \text { Energy consumption }\end{array}$ & 0.94 & 0.201 & - & 49.49 & - \\
\hline \multicolumn{6}{|l|}{ Cage at $28{ }^{\circ} \mathrm{C}$} \\
\hline $\begin{array}{l}\text { Retained energy }=-4.8448+0.2458 \\
\text { *Energy consumption }\end{array}$ & 0.95 & 0.213 & 92.84 & - & 0.25 \\
\hline $\begin{array}{l}\text { Heat production }=10.357 * \mathrm{e} \\
0.0293 * \text { Energy consumption }\end{array}$ & \multicolumn{5}{|c|}{ Japanese quails in floor pens } \\
\hline $\begin{array}{l}\text { Retained energy }=-5.1252+0.2329 \\
\text { *Energy consumption }\end{array}$ & 0.95 & 0.234 & 95.23 & - & 0.23 \\
\hline \multirow[t]{2}{*}{$\begin{array}{l}\text { Heat production }=13.044 * \mathrm{e} \\
0.0226 * \text { energy consumption }\end{array}$} & 0.94 & 0.234 & - & 55.74 & \\
\hline & \multicolumn{5}{|c|}{ European quails in cages } \\
\hline Cage at $18{ }^{\circ} \mathrm{C}$ & & & & & \\
\hline $\begin{array}{l}\text { Retained energy }=-7.833+0.2699 \\
\text { *Energy consumption }\end{array}$ & 0.91 & 0.269 & 107.85 & - & 0.27 \\
\hline $\begin{array}{l}\text { Heat production }=15.487 * \text { e } \\
0.0195^{*} \text { Energy consumption }\end{array}$ & 0.93 & 0.269 & - & 57.57 & \\
\hline \multicolumn{6}{|l|}{ Cage at $24{ }^{\circ} \mathrm{C}$} \\
\hline Heat production $=15.123 * \mathrm{e}^{0.02 * \text { Energy consumption }}$ & \multicolumn{5}{|c|}{ European quails in floor pens } \\
\hline $\begin{array}{l}\text { Retained energy }=-6.4589+0.2244 \\
\text { *Energy consumption }\end{array}$ & 0.99 & 0.274 & 107.15 & - & 0.22 \\
\hline Heat production $=17,315 * \mathrm{e}^{0,0172 * \text { Energy consumption }}$ & 0.95 & 0.274 & & - & 63.19 \\
\hline
\end{tabular}

gain from lowest to the highest temperature in Japanese (17 to 25\%) and European (27 to 28\%) quails. However, Japanese quails seem to lose body heat more easily with increasing temperature compared with European quails. Therefore, the lowest temperature stimulates the metabolizable energy intake and loss of body energy to the environment, resulting in higher metabolizable energy requirements for maintenance.

The estimated energy requirement for maintenance in the floor pen was 95.23 and $107.15 \mathrm{kcal} / \mathrm{kg}^{0.75} /$ day for Japanese and European quails (Table 3). Energy requirements for maintenance of Japanese quails housed in cages are smaller than those determined on the floor. However, energy requirements for maintenance of European quails in cages

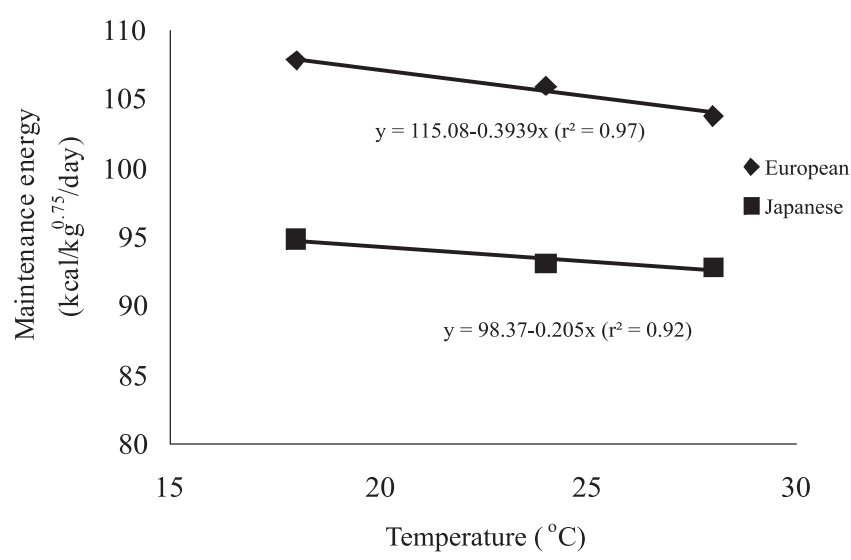

Figure 1 - Energy requirements for maintenance of quails housed in climate chambers with four room temperatures from 16 to 36 days of age. 
at 24 and $28{ }^{\circ} \mathrm{C}$ were lower but similar to that estimated for poultry housed on the floor at $18{ }^{\circ} \mathrm{C}$.

Lowest maintenance requirements of poultry housed in cages when compared with those created in floor pens are explained by the lower floor space for poultry and the increased energy expenditure with locomotor activities (Silva et al., 2004ab). However, the similarity of maintenance energy in floor pen with European quails at $18{ }^{\circ} \mathrm{C}$ was probably caused by production and heat loss to the environment by poultry. Results of this study support the theory of Balnaves et al. (1978) that energy for maintenance can be influenced by locomotion activities and room temperature. According to Ketelaars et al. (1985), poultry reared in cages have lower energy requirements for maintenance, related to the lower heat production and better efficiency of energy use in relation to poultry reared on the floor. According to Scott et al. (1982), energy spent on activities represents approximately $50 \%$ of the energy for maintenance in chickens housed on the floor and only $37 \%$ for poultry reared in cages.

Quails usually have constant habits of scratching feed and litter in addition to frequently fly on the facilities (Silva et al., 2004b). In this research, the higher maintenance energy for quails housed in floor pens over the poultry housed in cages and lower retention of energy intake for gain in quails housed on the floor support this hypothesis.

Energy requirements for maintenance determined with European quails were higher than those estimated for Japanese ones, regardless of housing system or breeding temperature. Lopez \& Lesson (2005), studying the use of metabolizable energy for poultry with different growth rates, observed lower rates of energy retention as protein and fat in commercial broilers (Ross) comparing the two slow-growing genotypes (Plymouth Roch Barred and rooster Leghorns). In addition, the metabolizable energy requirement for maintenance of quails was lower than those for broilers (Sakomura et al., 2005), pullets (Albino et al., 1994) and growth broilers breeders (Sakomura et al., 2003). Results suggest that energy requirements of quails differ between each other and, mainly from other species, indicating that these poultry have specific nutritional requirements.

Results for maintenance indicate that such factors as temperature and breeding system should be considered in defining nutrition plans for quails' genotype like the suggestion made by Rabello et al. (2004) to broiler breeders.

The energy was retained in the proportion of $22 \%$ energy intake in European quails reared on the floor; however, the estimate is lower than the utilization efficiency determined by Albino et al. (1994) in chickens
(55\%) and by Longo et al. (2006) in broilers (59\%). In addition, for each gram of feed consumed, European quails retained 27, 26 and 28\% energy when housed in cages at 18,24 and $28^{\circ} \mathrm{C}$, respectively. These estimates are below 69, 69 and 63\% efficiency of energy use determined by Sakomura et al. (2003) in broiler breeders during growth and housed in cages at 15,22 and $30^{\circ} \mathrm{C}$, respectively. The lower efficiency of energy utilization by quails can be justified by the loss of body heat, favored by lower surface:body volume relation (Macleod \& Dabhuta, 1997). Similarly, Silva et al. (2004ab) also found low efficiency of use by Japanese quails.

The net requirement for maintenance was determined by exponential regression equation of fasting heat production as function of metabolizable energy intake of poultry. The net energy for maintenance of European and Japanese quails housed in floor pen was higher than that estimated for quails housed in cages, indicating, again, increased heat production by the poultry reared on the floor compared with those in cages.

Concerning gain, there were variations in body weight, chemical composition and energy of the empty body of genotypes of quails (Table 4). Body weight, dry matter, crude fat and crude energy of the empty body of both genotypes increased while the water percentage decreased proportionally. Overall, the drop in water content and increased fat can be attributed to the inverse relationship between these two components.

Results of some experiments indicate negative correlations between water content and protein with advancing age in pullets (Martin et al., 1994) and broilers (Bartov \& Plavnik, 1998). Similarly, Neme et al. (2006) noted from studies on growth curves that fat deposition of light pullets tends to grow from 1 to 18 weeks of age, while water deposition decreases proportionately.

Fat, protein and crude energy in the empty body contents of European quails showed slight superiority to those observed in the empty body of Japanese quails, indicating that although genetically different, both quail species remain very similar to each other in body composition.

Using the linear regression equation of body energy as function of the empty body weight was possible to estimate the net energy requirement at $2.07 \mathrm{kcal} / \mathrm{g}$ gain for Japanese quails close to $2.14 \mathrm{kcal} / \mathrm{g}$ estimated for European quails (Table 5). The estimated net gain obtained with Japanese quails ( $2.07 \mathrm{kcal} / \mathrm{g}$ ) is similar to the $2.05 \mathrm{kcal} / \mathrm{g}$ estimated by Silva et al. (2004b) also with Japanese quails in the period from 15 to 32 days of age. 
Considering the efficiencies of using energy consumed to the net energy gain in empty body, gain energy demands determined in quails in floor pens were higher than those of poultry in cages, regardless of genotype. This result can be attributed to the lower efficiency of poultry housed in floor pens compared with those in cages, probably related to the increased locomotion activity of poultry in the facilities, which reflects a lower rate of fat deposition. Overall, Japanese quails require more energy per gram of weight gain than European quails in cages; however, they need less energy requirement for gain when housed on the floor, probably due to the intense motor activity of Japanese quails.

Values of required energy gain of $9.00 \mathrm{kcal} / \mathrm{g}$ of Japanese quails and $9.72 \mathrm{kcal} / \mathrm{g}$ of European quails housed in floor pens were above $3.25 \mathrm{kcal} / \mathrm{g}$ gain determined with pullets (Albino et al ., 1994) and $6.68 \mathrm{kcal} / \mathrm{g}$ gain in laying hens (Sakomura et al., 2005). This proves that there are differences between species regarding the energy requirement for gain, since quails require more energy per gram of gain than pullets and hens, probably by the acceleration of fat tissue gain at this stage, which precedes the onset of posture. The highest growth rate of adipose tissue in relation to the protein has a fundamental importance in determining the energy requirements for gain due to the higher cost of fat deposition, which is a tissue rich in dry matter, while the protein tissue contains from 2 to $3 \mathrm{~g}$ water/g retained protein, making it a lower deposition cost tissue (Silva et al., 1997).

Results indicate differences in energy nutritional requirements between quails improved for egg laying and those improved for meat production. The energy of maintenance includes the energy for basal metabolism, calorie increment, thermoregulation and activities (Sakomura et al., 2005), and the difference between the two quails species depends on environmental conditions, physical activity exerted by poultry and mainly on differences in deposition rates. Therefore, when determining the requirement for maintenance, one should take into account factors such as temperature, rearing system and quail genotype.

Table 4 - Average weight and chemical composition and empty body energy of European and Japanese quails based on age

\begin{tabular}{|c|c|c|c|c|c|c|c|c|}
\hline $\begin{array}{l}\text { Age } \\
\text { (days) }\end{array}$ & $\begin{array}{l}\text { Empty body } \\
\text { weight (g) }\end{array}$ & $\begin{array}{c}\text { Dry matter } \\
(\%)\end{array}$ & $\begin{array}{l}\text { Water } \\
(\%)\end{array}$ & $\begin{array}{c}\text { Mineral matter } \\
(\%)\end{array}$ & $\begin{array}{c}\text { Crude fat } \\
\text { (\%) }\end{array}$ & $\begin{array}{c}\text { Crude } \\
\text { protein }(\%)\end{array}$ & $\begin{array}{l}\text { Crude energy } \\
\text { (kcal) }\end{array}$ & $\begin{array}{c}\text { Body crude } \\
\text { energy }(\mathrm{kcal} / \mathrm{g})^{1}\end{array}$ \\
\hline & & \multicolumn{7}{|c|}{ Japanese quails } \\
\hline 16 & 67.71 & 24.01 & 75.99 & 3.39 & 2.47 & 16.85 & 1.070 & 72.45 \\
\hline 21 & 91.31 & 26.03 & 73.97 & 3.07 & 2.64 & 20.68 & 1.199 & 109.48 \\
\hline 26 & 113.86 & 26.82 & 73.18 & 2.95 & 3.54 & 20.93 & 1.311 & 149.27 \\
\hline 31 & 133.73 & 29.33 & 70.67 & 2.99 & 4.03 & 19.71 & 1.488 & 198.99 \\
\hline \multirow[t]{2}{*}{36} & 146.88 & 29.52 & 70.48 & 3.23 & 7.18 & 19.38 & 1.623 & 238.38 \\
\hline & & \multicolumn{7}{|c|}{ European quails } \\
\hline 16 & 93.15 & 25.52 & 74.48 & 3.28 & 3.18 & 17.19 & 1.195 & 111.31 \\
\hline 21 & 130.20 & 27.11 & 72.89 & 3.14 & 3.34 & 19.20 & 1.342 & 174.73 \\
\hline 26 & 154.93 & 29.09 & 70.91 & 3.47 & 4.06 & 20.35 & 1.438 & 222.79 \\
\hline 31 & 192.40 & 29.17 & 70.83 & 3.13 & 4.94 & 19.72 & 1.651 & 317.65 \\
\hline 36 & 227.25 & 30.18 & 69.82 & 2.93 & 8.08 & 19.60 & 1.728 & 392.69 \\
\hline
\end{tabular}

${ }^{1}$ Body crude energy was obtained by the product of crude energy with the empty body weight.

Table 5 - Net and dietary requirement of metabolizable energy for gain in Japanese and European quails housed in two breeding systems

\begin{tabular}{|c|c|c|c|c|c|}
\hline Breeding system & Equation & $\mathrm{r}^{2}$ & $\begin{array}{l}\text { Gain net } \\
\text { requirement } \\
\text { (kcal/g) }\end{array}$ & $\begin{array}{c}\text { Use } \\
\text { efficiency } \\
(\%)\end{array}$ & $\begin{array}{c}\text { Gain } \\
\text { requirement } \\
(\mathrm{kcal} / \mathrm{g})^{1}\end{array}$ \\
\hline & & & Japanese quails & & \\
\hline Cage & Body energy $=-75.732+2.0727 *$ Body weight & 0.98 & 2.07 & 0.25 & 8.28 \\
\hline Floor pen & Body energy $=-75.732+2.0727 *$ Body weight & 0.98 & $\begin{array}{l}2.07 \\
\text { European quails }\end{array}$ & 0.23 & 9.00 \\
\hline Cage & Body energy $=-97.465+2.1387 *$ Body weight & 0.99 & 2.14 & 0.28 & 7.64 \\
\hline Floor pen & Body energy $=-97.465+2.1387 *$ Body weight & 0.99 & 2.14 & 0.22 & 9.72 \\
\hline
\end{tabular}

${ }^{1}$ Gain requirement was obtained by the ratio of gain net requirement with use efficiency. 


\section{Conclusions}

Room temperature, breeding system and quail lineage affect estimates of energy requirement. The following equations are proposed to estimate energy requirements for maintenance and gain in weight of quails from 16 to 36 days of age: Japanese quails - cage: energy requirement $(\mathrm{kcal} /$ poultry/day $)=$ body weight $^{0.75} *(98.37$ $0.205 *$ temperature) $+8.28 *$ weight gain; and floor pens: energy requirement $(\mathrm{kcal} /$ poultry/day $)=$ body weight ${ }^{0.75} *$ (98.37 - 0.205*temperature) + 9.00*weight gain; European quails - cage: energy requirement $(\mathrm{kcal} /$ poultry/day $)=$ body weight ${ }^{0.75 *}$ (115.08 - 0.3939*temperature $)+7.64 *$ weight gain; and floor pens: energy requirement (kcal/poultry/ day) $=$ body weight $^{0.75 *}(115.08-0.3939 *$ temperature $)+$ $9.72 *$ weight gain.

\section{Acknowledgements}

The authors thank CNPq, for funding the project and Capes, for granting the scholarship.

\section{References}

ALBINO, L.F.T.; FIALHO, F.B.; BELLAVER, C. et al. Estimativas das exigências de energia e proteína para frangas de postura em recria. Pesquisa Agropecuária Brasileira, v.29, p.1625-1629, 1994.

ASSOCIATION OF OFFICIAL ANALYTICAL CHEMISTS - AOAC. Official methods of analysis. 15.ed. Arlington: 1990.

BALNAVE, D.; FARRELL, D.J.; CUMING, R.B. The minimum metabolizable energy requerimento of laying hens. World's Poultry Science, v.34, p.149-154, 1978.

BARTOV, I.; PLAVNIK, I. Moderate excess of dietary protein increases breast meat yield of broiler chicks. Poultry Science, v.77, p.680-688, 1998.

EMMANS, G.C. Effective energy: a concept of energy utilization applied across species. British Journal of Nutrition, v.71, p.801-821, 1994

FARRELL, D.J. General principles and assumptions of calorimetry. In: MORRIS, T.R.; FREEMAN, B.M. (Eds.). Energy requirementes of poultry. Edinburgh: British Poultry Science, 1974. p.1-23.

KETELAARS, E.H.; ARETS, A.; VAN DER HEL, A.J. et al. Effect of housing systems on the energy balance of laying hens. Journal Agricultural Science, v.33, p.35-43, 1985.

LOFGREEN, G.P.; GARRETT, W.N. A system for expressing net energy requirements and feed values for growing and finishing beef cattle. Journal of Animal Science, v.27, n.3, p.793-806, 1968.

LONGO, F.A.; SAKOMURA, N.K.; RABELLO, C.B.V. et al. Exigências energéticas para mantença e para o crescimento de frangos de corte. Revista Brasileira de Zootecnia, v.35, n.1, p.119-125, 2006.

LOPEZ, G.; LEESON, S. Utilization of metabolizable energy by young broiler and birds of intermediate growth rate. Poultry Science, v.84, p.1069-1076, 2005.
MaCLEOD, M.G.; DABHUTA, L.A. Diet selection by japanese quail (Coturnix coturnix japonica) in relation to ambient temperature and metabolic rate. British Poultry Science, v.38, p.586-589, 1997.

MARSDEN, A.; MORRIS, T.R. Quantitative review of the effects of environmental temperature on food intake, egg output and energy balance in laying pullets. British Poultry Science, v.32, p.821-827, 1987.

MARTIN, P.A.; BRADFORD, G.D.; GOUS, R.M. A formal method of determining the dietary amino acid requeriments of laying-type pullets during their growing period. British Poultry Science, v.35, p.709-724, 1994.

NEME, R.; SAKOMURA, N.K.; FIALHO, F.B. et al. Modelling energy utilization for laying type pullets. Revista Brasileira de Ciência Avícola, v.7, n.1, p.39-46, 2005.

NEME, R.; SAKOMURA, N.K.; FUKAYAMA, E.H. et al. Curvas de crescimento e de deposição dos componentes corporais em aves de postura de diferentes linhagens. Revista Brasileira de Zootecnia, v.35, n.3, p.1091-1100, 2006.

RABELLO, C.B.V.; SAKOMURA, N.K.; LONGO, F.A. et al Efeito da temperatura ambiente e do sistema de criação sobre as exigências de energia metabolizável para mantença de aves reprodutoras pesadas. Revista Brasileira de Zootecnia v.33, n.2, p.382-390, 2004.

SAKOMURA, N.K.; BASAGLIA, R.; SÁ-FONTES, C.M.L. et al Modelo para estimar as exigências de energia metabolizável para poedeiras. Revista Brasileira de Zootecnia, v.34, n.2, p.575-583, 2005.

SAKOMURA, N.K.; SILVA, R.; COUTO, H.B. et al. Modeling metabolizable energy utilization in broiler breeder pullets. Poultry Science, v.82, p.419-427, 2003.

SCOTT, M.L.; NESHEIM, M.C.; YOUNG, R.J. Nutrition of the chicken. 3.ed. Ithaca: M.L. Scott, 1982. 562p.

SILVA, D.J.; QUEIROZ, A.S. Análise de alimentos: métodos químicos e biológicos. 3.ed. Viçosa, MG: UFV, 2002. 235p.

SILVA, I.J.O.; BARBOSA FILHO, J.A.D.; SILVA, M.A.N. et al. Influência do sistema de criação nos parâmetros comportamentais de duas linhagens de poedeiras submetidas a duas condições ambientais. Revista Brasileira de Zootecnia, v.35, n.4, p.1439-1446, 2006.

SILVA, J.H.V.; COSTA, F.GP. Tabelas para codornas japonesas e europeias: tópicos especiais, composição de alimento e exigências nutricionais. 2.d. Jaboticabal: FUNEP, 2009. 107p.

SILVA, J.H.V.; COSTA, F.G.P.; SILVA, E.L. et al. Exigências nutricionais de codornas. In: CONGRESSO INTERNACIONAL DE COTURNiCUlTuRA, 3., 2007, Lavras. Palestra... Lavras: UFLA, 2007. p.42-62.

SILVA, J.H.V.; SILVA, M.B.; JORDÃO FILHO, J. et al. Exigências de mantença e de ganho de proteína e de energia em codornas japonesas (Coturnix coturnix japonica) na fase de 1 a 12 dias de idade. Revista Brasileira de Zootecnia, v.33, n.5, p.1209-1219, 2004a.

SILVA, J.H.V.; SILVA, M.B.; JORDÃO FILHO, J. et al. Exigências de mantença e de ganho em proteína e energia em codornas japonesas (Coturnix coturnix japonica) na fase de 15 a 32 dias. Revista Brasileira de Zootecnia, v.33, n.5, p.1220-1230, 2004b.

SILVA, R.; SAKOMURA, N.K.; REZENDE, K.T. et al. Exigências de energia metabolizável para frangas de postura de 1 a 18 semanas de idade. Revista Brasileira de Zootecnia, v.26, n.1, p.111-120, 1997.

WOLYNETZ, M.S.; SIBBALD, I.R. Need for comparative slaughter experiments in poultry research. Poultry Science, v.66, p.1961-1972, 1987. 